\title{
STUDI EKOLOGIS DALAM PERENCANAAN RUMAH TINGGAL DI NGANJUK
}

\author{
Juwito Junianto HW, Erna Winarsih \\ Mahasiswa Program Studi Magister Arsitektur Pascasarjana Universitas Merdeka Malang \\ Dosen Program Studi Magister Arsitektur Pascasarjana Universitas Merdeka Malang \\ Dosen Program Studi Magister Arsitektur Pascasarjana Universitas Merdeka Malang \\ Email: vernakular_konsultan2@yahoo.co.id
}

\begin{abstract}
Key words: ecological architecture, residential, nganjuk

To accommodate the daily activities of a small family, efforts are needed to present a representative residence. harmony with nature, humans, and the built-in environment, sustainably and sustainably is the Start Point. The 'Ecological Architecture' approach in planning the Residence in Nganjuk is chosen as the guiding line. The basic thing is whether there is an alignment between the architectural concept and the end result of his work. This research methodology uses descriptive and literature studies. this research attempts to analyze the design work with the concept of ecological architecture, based on the theory of ecological architecture from (Heinz Frick., 2006). The results of this study indicate that this Residence is a small example of the application of 'Ecological Architecture'. The parameters can be seen from Adjusting design work to the environment, maintaining environmental resources, saving natural energy sources, utilizing natural resources around the area for building systems, both related to building materials and for building utilities. Implement $4 \mathrm{R}$ (reduce, reuse, recycle, repair) on the material used. the type of material that can be returned to nature in accordance with the cycle. with a building orientation pattern (east-west) to dominant vista facing north-south to become the center of sensing into the interior layout along with the parks and water spots.
\end{abstract}

\begin{abstract}
Abstrak
Untuk mewadahi aktifitas sehari-hari sebuah keluarga kecil, diperlukan upaya menghadirkan hunian yang representatif. keselarasan dengan alam, manusia, dan tata lingkungan binaan, secara berkesinambungan dan lestari merupakan Start Point nya. Pendekatan 'Arsitektur Ekologis' dalam perencanaan Rumah Tinggal di Nganjuk ini, dipilih sebagai garis pandunya. Hal yang mendasar adalah apakah ada, keselarasan antara konsep arsitekturalnya dengan hasil akhir karyanya. Metodologi penelitaian ini menggunakan deskriptif dan strudi literatur. penelitian ini berusaha untuk menganalisis karya Desain dengan konsep arsitektur ekologis, didasarkan dengan teori arsitektur ekologis dari (Heinz Frick., 2006). Hasil dari penelitian ini menunjukkan bahwa Rumah Tinggal ini, merupakan contoh kecil penerapan 'Arsitektur Ekologis'. Parameternya dapat terlihat dari Penyesuaian karya desain terhadap lingkungan, memelihara sumber lingkungan, menghemat sumber energi alam, memanfaatkan sumber daya alam sekitar kawasan untuk sistem bangunan, baik yang berkaitan dengan material bangunan maupun untuk utilitas bangunan. Menerapkan 4R (reduce, reuse, recycle, repair) pada material yang dipakai. jenis material yang dapat dikembalikan lagi ke alam sesuai dengan siklusnya. dengan pola tata letak orientasi bangunan (timur-barat) hingga dominan vista menghadap utara-selatan menjadi pusat penginderaan kedalam tata ruang interior beserta spot taman-taman dan airnya.
\end{abstract}

Kata-kunci: arsitektur ekologis, rumah tinggal, nganjuk

@ 2017 The Authors. Published by GKAK UNMER Malang

*Corresponding Author: vernakular_konsultan2@yahoo.co.id 


\section{Pendahuluan}

\section{Latar Belakang Persoalan}

Untuk mempermudah mengidentifikasi alternatif solusi atau dalam wujud sebuah karya (desain arsitektur), diperlukan guidlines. Apakah konsep Arsitekturnya ? dan adakah Sinergitas antara konsep arsitekturnya dengan hasil akhir karyanya?

Dalam kajian ini peneliti akan mengkaji mengenai Arsitektur Ekologis serta penerapannya yang lebih spesifik pada 'Rumah Tinggal' di Nganjuk.

\section{Tinjauan Pustaka}

Arsitektur ekologis merupakan pembangunan berwawasan lingkungan, dimana memanfaatkan potensi alam semaksimal mungkin (sumber:https://id.wikipedia.org., 2016).

Berdasarkan Heinz Frick (2006), Arsitektur Ekologis dapat dimaknai sebagai pembangunan lingkungan binaan sebagai kebutuhan hidup manusia dalam hubungan timbal balik dengan lingkungan alamnya yang mempertimbangkan keberadaan dan kelestarian alam, disamping konsep-konsep arsitektur bangunan itu sendiri.

Senada dengan hal tersebut Yuliani (2012), mengintepretasikan Ekologis Arsitektur adalah konsep membangun yang memperhatikan faktor keseimbangan lingkungan alam dan lingkungan binaan. Perancangan berkonsep Ekologi Arsitektur merupakan wujud simbiosis mutualisme lingkungan dengan bangunan sehingga memberikan kontribusi terhadap siklus alam

Perencanaan eko arsitektur dimengerti sebagai perencanaan berbasis ekologi yang merupakan hubungan timbal balik antara makhluk hidup dengan lingkungannya. Dalam implementasinya mengedepankan pemilihan material yang tepat, teknologi struktur ramah lingkung, dengan pencahayaan danpengudaraan ventilasi silang serta sehingga simbiosis itu terjaga. (Diana susilowati, 2013).

Rumah dapat dimengerti sebagai tempat perlindungan, untuk menikmati kehidupan, beristirahat dan bersuka ria bersama keluarga. di dalam rumah, penghuni memperoleh kesan pertama dari kehidupanya di dalam dunia ini. rumah harus menjamin kepentingan keluarga, yaitu untuk tumbuh, memberi kemungkinan untuk hidup bergaul dengan tetangganya; lebih dari itu, rumah harus memberi Ketenangan, Kesenangan, Kebahagiaan Dan Kenyamanan Pada Segala Peristiwa Hidupnya (Heinz Frick, 2006).

(Heinz Frick, 2006) memiliki beberapa prinsip bangunan ekologis yang Antara lain seperti:

1. Penyesuaian terhadap lingkungan alam setempat,

2. Menghemat sumber energi alam yang tidak dapat diperbaharui dan Menghemat penggunaan energi,

3. Memelihara sumber lingkungan (udara, tanah, air), memelihara dan Memperbaiki peredaraan alam,

4. Mengurangi ketergantungan kepada sistem pusat energi (listrik, air) dan limbah (air limbah dan sampah),

5. Kemungkinan penghuni menghasilkan sendiri kebutuhannya seharihari,

6. Memanfaatkan sumber daya alam sekitar kawasan perencanaan untuk sistem bangunan, baik yang berkaitan dengan material bangunan maupun untuk utilitas bangunan (sumber energi, Penyediaan air). 


\section{Studi Ekologis dalam Perencanaan Rumah Tinggal di Nganjuk}

Juwito, Junianto HW, Erna Winarsih

Patokan Rumah yang sehat dan Ekologis meliputi:

1. Menciptakan kawasan penghijauan diantara kawasan pembangunan sebagai paru-paru hijau,

2. Memilih tapak bangunan yang sebebas mungkin dari gangguan/radisi geobiologis dan meminimalkan medan elektromagnetik buatan,

3. Mempertimbangkan rantai bahan dan menggunakan bahan bangunan alamiah,

4. Menggunakan ventilasi alam untuk menyejukkan udara dalam bangunan,

5. Menghindari kelembaban tanah naik kedalam konstruksi bangunan dan memajukan sistem bangunan kering,

6. Memilih lapisan permukaan dinding dan langit-langit ruang yang mampu mengalirkan uap air,

7. Menjamin kesinambungan pada struktur sebagai hubungan antara masa pakai bahan bangunan dan struktur bangunan,

8. Mempertimbangkan bentuk/proporsi ruang berdasarkan aturan harmonikal,

9. Menjamin bahwa bangunan yang direncanakan tidak menimbulkan masalah lingkungan dan membutuhkan energi sesedikit mungkin,

10. Menciptakan bangunan bebas hambatan sehingga gedung dapat dimanfaatkan oleh semua penghuni. (Heinz Frick, 2006)

\section{Permasalahan}

Apakah 'Rumah Tinggal' di Nganjuk, dalam penelitian ini sudah menerapkan konsep Arsitektur Ekologis? (Arsitektur Peka Lingkung dan lestari?).

\section{Tujuan Penulisan}

Penelitian ini bertujuan untuk mempelajari, mengidentifikasi, menganalisis objek kajian 'Rumah Tinggal' di Nganjuk, menerapkan konsep Arsitektur Ekologis (Arsitektur Peka Lingkung dan lestari?) berdasarkan teori Heinz Frick (2006).

\section{Metodologi}

Dalam penyusunan penelitian ini, penulis menggunakan metode penelitian deskriptif dan studi literatur. Penelitian deskriptif adalah penelitian yang berusaha mendeskripsikan suatu gejala, peristiwa, kejadian yang terjadi pada saat sekarang. (Diana susilowati, Irma Ramanadhia., 2013).

Penelitian deskriptif ini dilakukan dengan tujuan utama, yaitu menggambarkan secara sistematis fakta dan karakteristik objek atau subjek yang diteliti secara tepat.

Dilakukanya penyandingan studi literatur dan studi preseden di lapangan yang relevan hal ini untuk mengetahui potensi dan kendala lingkungan serta persepsi penerapan konsep Arsitektur Ekologi sebagai dasar metode perencanaan dan perancangan. Kajian teori menggunakan teori Ekologi Arsitektur dari Heinz Frick. 


\section{Pengumpulan Data}

Tahap pengumpulan data mengenai karakteristik ekologis pada tapak dikaitkan dengan hasil karya desain, baik site planning, lay out planning, maupun lansekaping. Selain dengan melakukan obeservasi, pendokumentasian dan wawancara, juga menggunakan studi pustaka dari literatur sekait.

Pada proses metode perancangan yang digunakan yaitu metode intuitif dan metode pragmatik. Metode intutif digunakan untuk memasukkan konsep ekologis sedangkan pragmatik, merupakan tahap transformasi konsep perencanaan dan perancangan secara grafis ke dalam gambar perencanaaan dan perancangan sebagai jawaban atas rumusan permasalahan yang ada.

Tahap sintesa data akan didapatkan dengan menggabungkan parameter yang telah dibuat sebelumnya disesuaikan dengan tinjauan dari objek penelitian sehingga mendapatkan jawaban atas review karya ini.

Tahap Evaluasi, hasil solusi desain yang sesuai dengan kebutuhan ruang yang diperlukan dengan konsep Arsitektur ekologis sebagai penerapanya.

\section{Analisis Data}

Tahap analisis data yang dilakukan yaitu dengan menggunakan metode deskriftif. Dalam tahap ini, diadakan survey lapangan dari lokasi tapak dan eksiting tapak untuk selanjutnya disarikan menjadi bahan temuan penelitian.

\section{Analisis dan Interpretasi}

Objek penelitian berada di Jl.Semeru 135 Banaran, Pace, kabupaten Nganjuk, propinsi Jawa TimurIndonesia. Tempertur udara berkisar antara 21-33 derajat celcius. Merupakan kota midle yang berpengaruh dengan potensi bentangan lahan pertanianya.

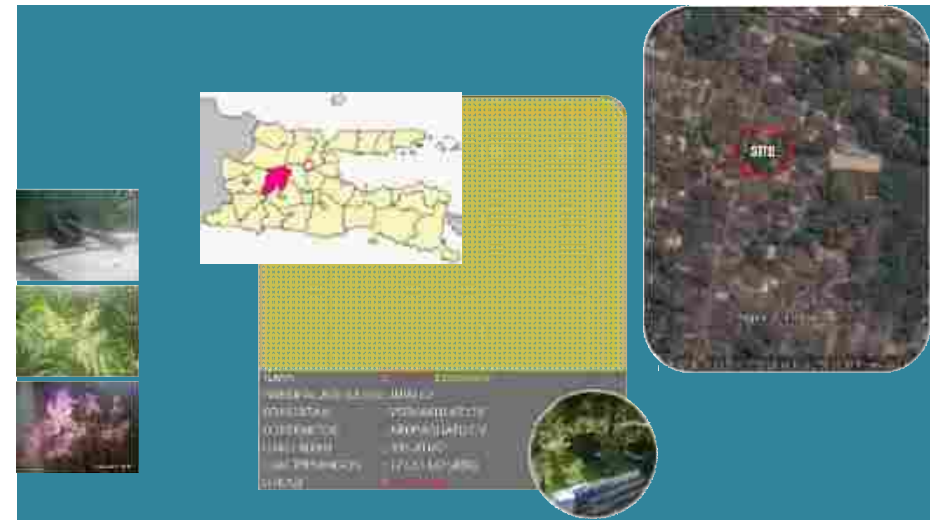

Gambar 1. Site objek penelitian 'Rumah Ekologis' di Nganjuk, terletak 11 km arah tenggara kota nganjuk. 


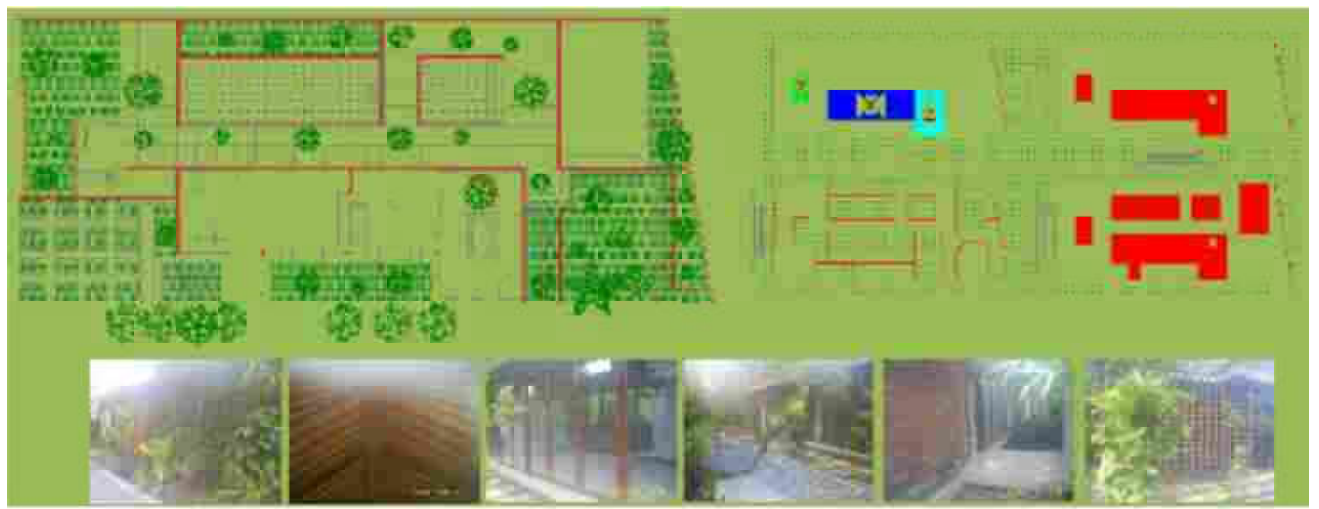

Gambar 2. Konsep dasar pola masa dan sebaran ruang 'geometry' the geometry of art and life (Anthony C.Antoniades., (1992)

Pada analisis dan pembahasan ini, penulis ingin membandingkan penerapan Arsitektur Ekologis sesuai patokan (Heinz Frick, 2006) pada 'Rumah Tinggal' di Nganjuk, diantaranya berupa:

1. Menciptakan kawasan penghijauan diantara kawasan pembangunan sebagai paru-paru hijau,

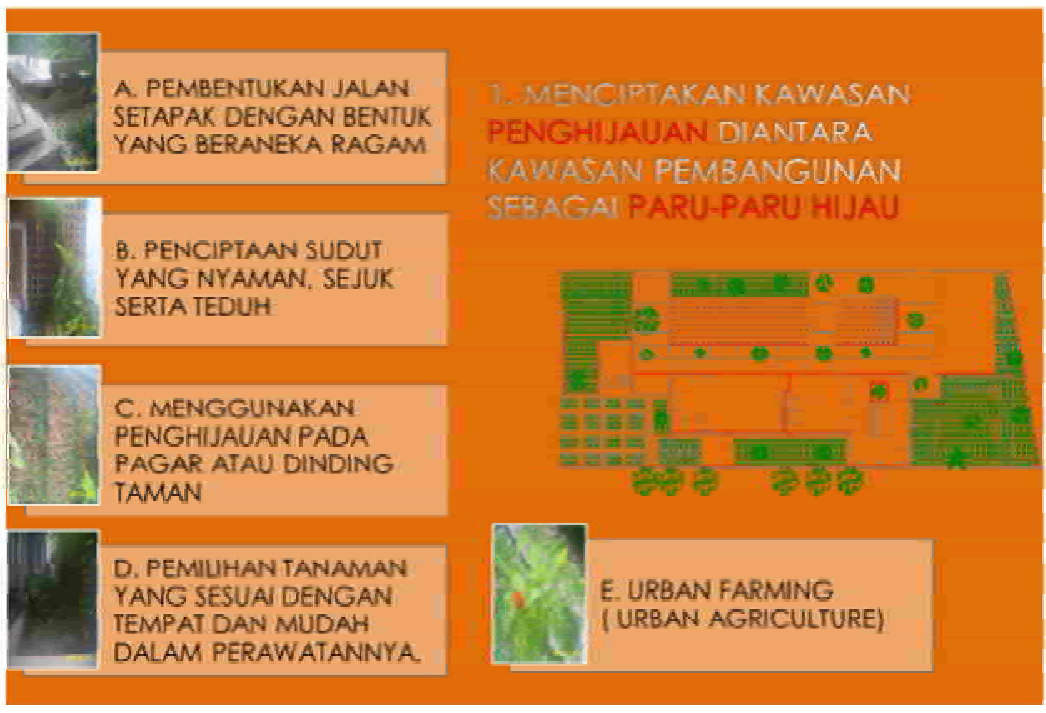

Gambar 3. Penerapan konsep penghijauan yang memberikan kontribusi terhadap kenyamanan iklim mikro, meso dan makro kawasan.

Urban farming (urban agriculture) ini memiliki fungsi sebagai berikut diantaranya:

a. Mengurangi pemanasan global (global warming)

b. Menciptakan view dan vista yang menarik

c. Memperbaiki kesuburan tanah

d. Penghematan karena sumber nabati dapat dihasilkan sendiri 
Pada objek penelitian Kebun sayur ini ditanam pada lahan luas, berupa tanaman sayuran berupa kangkung, bayam,cabai, tomat, kemangi, daun ketela rambat, jagung dan lahan terbatas berupa vertical agricultur berupa bag log-bag log jamur tiram yang ditempatkan pada struktur bata miring berlubang dan kerangka untuk tanaman merambat pada aplikasinya diwujudkan pada atap car port berupa tanaman anggur dipadukan tanaman sulur-sulurnya.

2. Mempertimbangkan rantai bahan dan menggunakan bahan bangunan alamiah,

Pengaruh ekologi lingkungan dan fisika bangunan turut berkontribusi dalam pekembangan bahan yang teraplikasi. Bahan bangunan yang alami tidak mengandung zat adictif yang dapat menurunkan nilai kesehatan manusia.

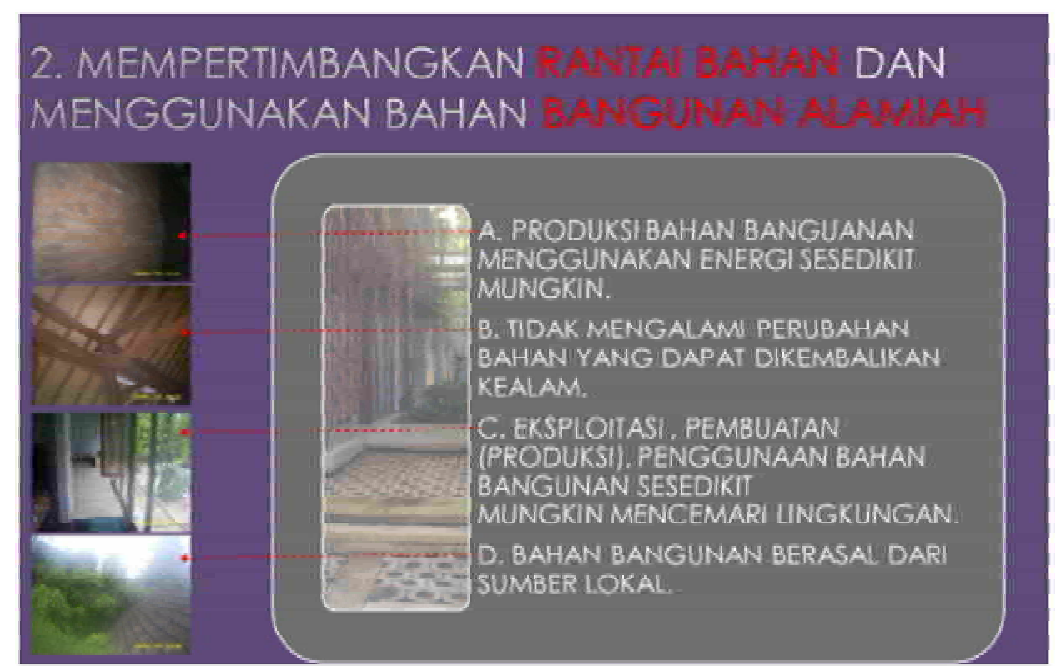

Gambar 4. Pertimbangan aplikatif bahan bangunan regeneratif, dapat digunakan kembali, bahan bangunan daur ulang, dengan transformasi sederhan beserta bahan bangunan komposit.

Bahan regeneratif ; kayu 'kelapa' teraplikasi pada seluruh konstruksi dan struktur bangunan, mulai dari kolom, balok, jurai, nok, usuk, reng, plafond beserta slimar jendela, maupun pintu vertikal yang membatasi ruang dalam dan luar. Bahan kayu kelapa didapatkan di daerah Baron, merupakan salah satu kecamatan di Nganjuk, Lebih kurang $12 \mathrm{KM}$ dari lokasi penelitian. dari aplikan terampil kayupun dipertimbangkan dengan memakai keseluruhan tenaga setempat.

Bahan digunakan kembali/ daur ulang ; batu 'bata merah' untuk dinding rumah. Keseluruhan dinding menggunakan bata setempat, mulai dari pencetakan, pembakaran dan beserta tenaga terampil lokal untuk aplikanya. Material lokal dan tenaga lokal diikat dalam karya disain mengingatkan kita akan proses pembangunan vernakular. Potongan batu-bata yang tidak terpakai diaplikasikan pada fasade taman ditata sedemikian, rapi, dan menarik untuk meminimalkan kesia-siaan, selain sebagai elemen arsitektural.

Bahan transformasi sederhana ; genteng 'beton' dipilih untuk melindungi rumah dari terik matahari dan hujan beserta material 'laten' lain yaitu jatuhnya buah mangga dll. Dominasi peneduh yang hampir menutupi $40 \%$ genteng beton dari terik merupakan pilihan dan kesekuensi. Satu pohon 


\section{Studi Ekologis dalam Perencanaan Rumah Tinggal di Nganjuk \\ Juwito, Junianto HW, Erna Winarsih}

besar dapat disetarakan dengan 5 unit air conditioner. Yang dioperasikan selama 20 jam setiap hari (Heinz Frick, 2006).

Faktor kuat tekan genteng menjadi dasar utama pemilihan. Dari hasil amatan tempaan buah mangga yang jatuh relatif memberikan jaminan material atap ini tidak mudah pecah.

Bahan bangunan komposite ; dak 'beton' pada atap rg. toilet dan rg.dapur. diterapkan untuk memberikan perlindungan atap. Pada mulanya diatas dag ditanami rumput hijau grass roof sebagai penghamparnya. Karena dibutuhkan perlakuan ekstra maka kondisi cuaca ditambah kurang diperhatikan perawatanya perlahan rumput penghampar mati karena tidak terjaga kesuburanya.

3. Menggunakan ventilasi alam untuk menyejukkan udara dalam bangunan,

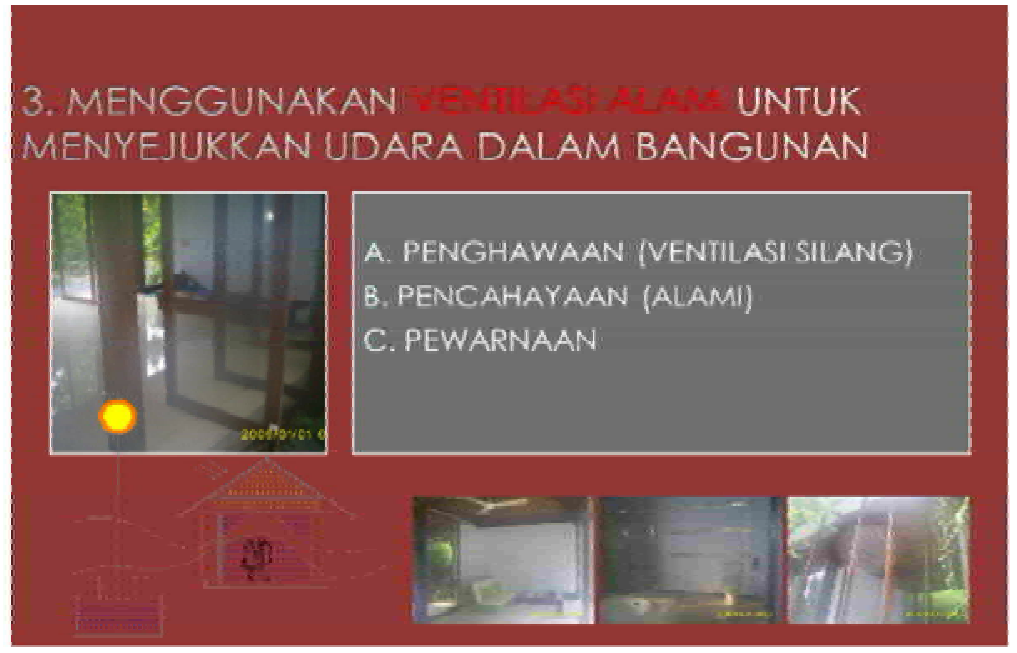

Gambar 5. Dalam mewujudkan persyaratan kenyamanan ruang dalam. yaitu sinar matahari dan orientasi bangunan, angin, dan pengudaraan ruangan, suhu dan perlindungan terhadap panas, curah hujan dan kelembapan udara.

Orientasi bangunan dan sinar terang yang melimpah ditempatkan diantara lintasan matahari (timurbarat) dengan menggunakan potensi angina sebagai penggerak sirkulasi alaminya. Bentuk denah yang terbuka dan mengalir antara (ruang luar dan ruang dalam) merupakan pengatur iklim-mikro dan makronya. Dalam hal ini tidak hanya perlu diperhatikan sinar matahari yang menerangi dan mengakibatkan panas saja, melainkan juga memperhatikan arah angin yang memberi kesejukan.. Konsep cross ventilation diaplikasikan pada objek kajian. Pemanfaatan Angin sebagai ventilasi silang sistem pengudaraan alami yang secara terus-menerus menyejukkan ruangan sehingga proses penguapan ini memberikan besar kontribusinya terhadap kenyamanan.

4. Menghindari kelembaban tanah naik kedalam konstruksi bangunan dan memajukan sistem bangunan kering, 
LOCAL WISDOM, Vol. 10 No. 2 Juli 2018

Local Wisdom Scientific Online Journal

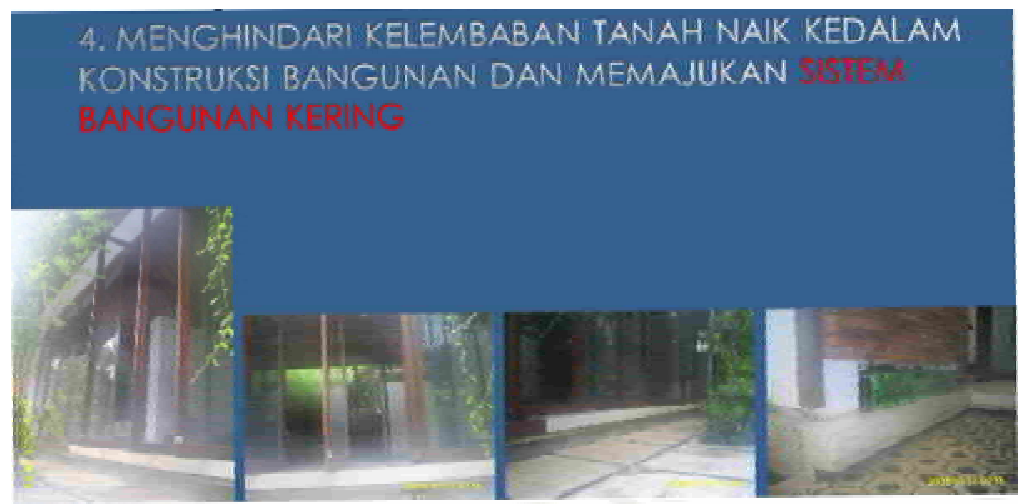

Gambar 6. Peninggian kaki bangunan dimaksudkan untuk memberikan deletasi efek air tanah naik kepermukaan, dengan memajukan sistem bangunan kering (peninggian lantai).

Peil lantai dari muka tanah asli dan atau jalan lingkung dinaikkan $45 \mathrm{~cm}$. Naiknya peil ini memberikan sumbangan positif view pengindra terhadap tinggi dan proporsi bangunan dari jalan. Tidak terdapatnya air tanah menembus kelantai membuat aktifitas lebih sehat dan higienis.

5. Memilih lapisan permukaan dinding dan langit-langit ruang yang mampu mengalirkan uap air,

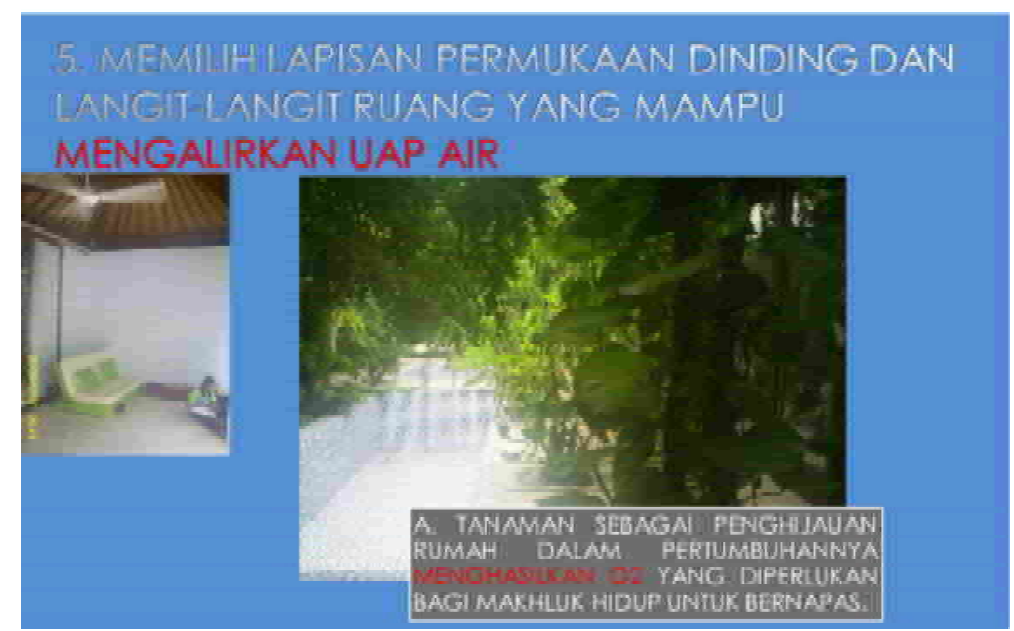

Gambar 7. Paparan terik dari langit mengenai vegetasi dan permukaan air kolam yang dihalau angin, menimbulkan uap air yang masuk menerpa kedalam interior ruang rumah secara mudah.

Pemilihan permukaan lapisan dinding dan lapisan langit - langit ruang termasuk dalam upaya ekologis. upaya ini dilakukan untuk mengalirkan uap air, mengatur tata udara dan suhu udara yang optimal.

Pemilihan lapiasan permukaan dinding yang bisa dibuka tutup sesuai kebutuhan, dengan penghawaan sistem sirkulasi silang yang diterapkan dalam rumah ini, mempermudah uap air untuk masuk dan 


\section{Studi Ekologis dalam Perencanaan Rumah Tinggal di Nganjuk}

Juwito, Junianto HW, Erna Winarsih

mendinginkan ruangan. Pertukaran udara yang baik menyejukkan dan menyehatkan ruang. Kenyamananpun diperoleh dengan mudah dan murah.

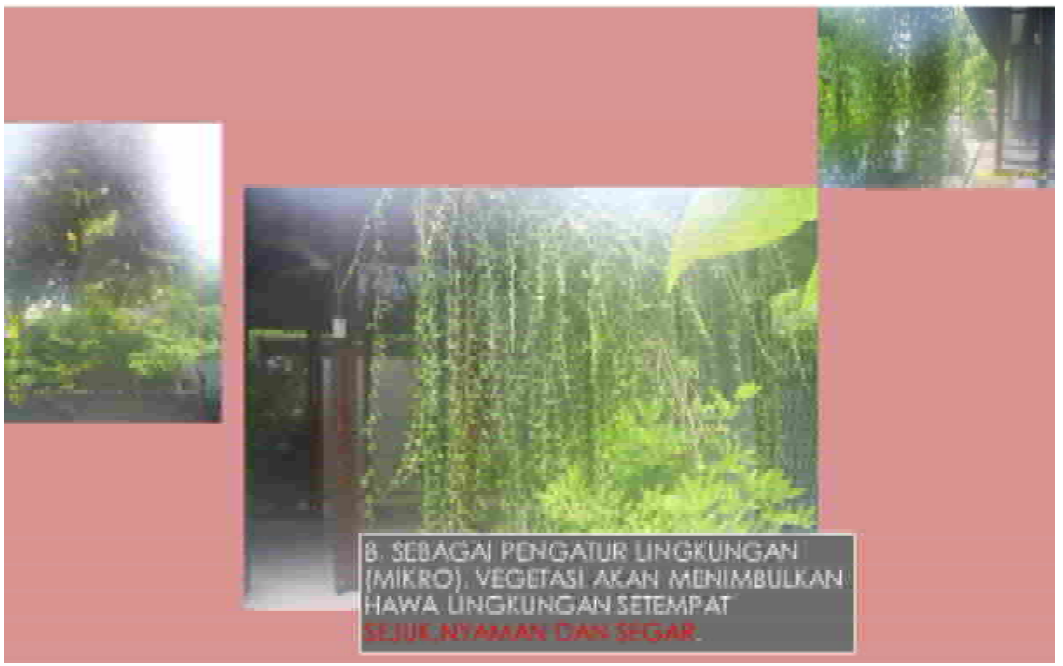

Gambar 8. Sejuk, nyaman dan segar diraskan dalam lingkung mikro rumah. Selain sebagai pengatur siklus vegetasi juga dapat dimanfaatkan sebagai buffer alam.

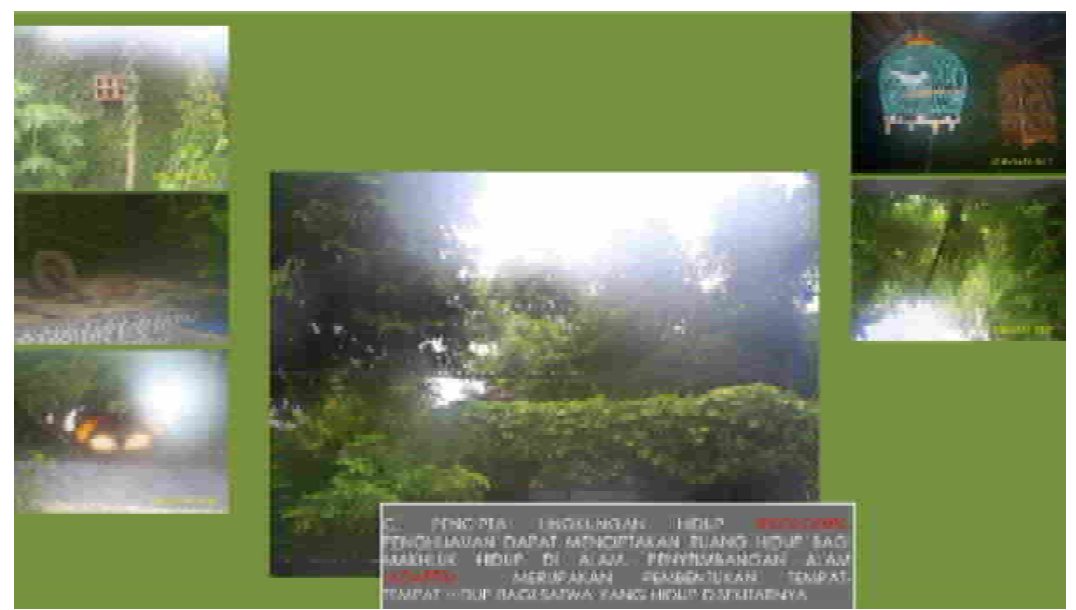

Gambar 9. Kondisi bentukan vegetasi menarik satwa, untuk hidup dan bernaung di iklim mikro site.

Penghijauan dapat memicu kenyamanan ruang hidup dan media pembentuk hidup bagi stawa. Bentukan vegetasi lingkung yang asri pada objek penelitian, dapat ditemui endemik satwa tropis, diantaranya burung-burung liar, reptil, kupu-kupu, bunglon, serangga, ular pohon, capung, katak, bekicot, dll. 


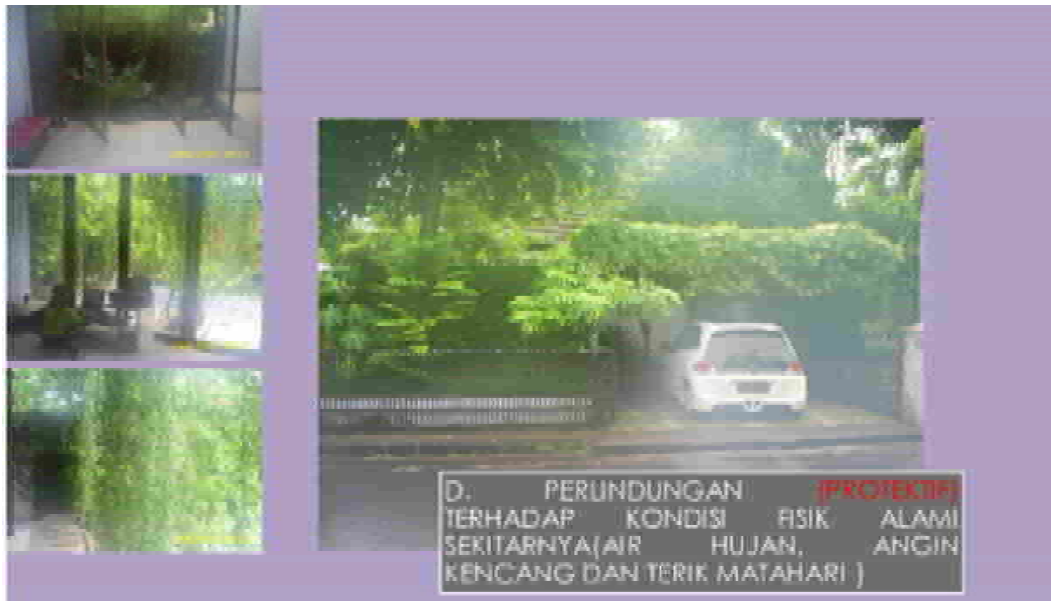

Gambar 10. Vegetasi merupakan Protektif alami dari terik matahari, kesilauan, tempias hujan, angin kencang, dan efek estetika vista.

Pemanfaatan tanaman sulur-sulur pada aplikasi lansekap rumah, memberikan sumbangsih optimal terhadap iklim mikro. Atap car port dan shadow sun screen tanaman apik tertata dan harmonis alami.

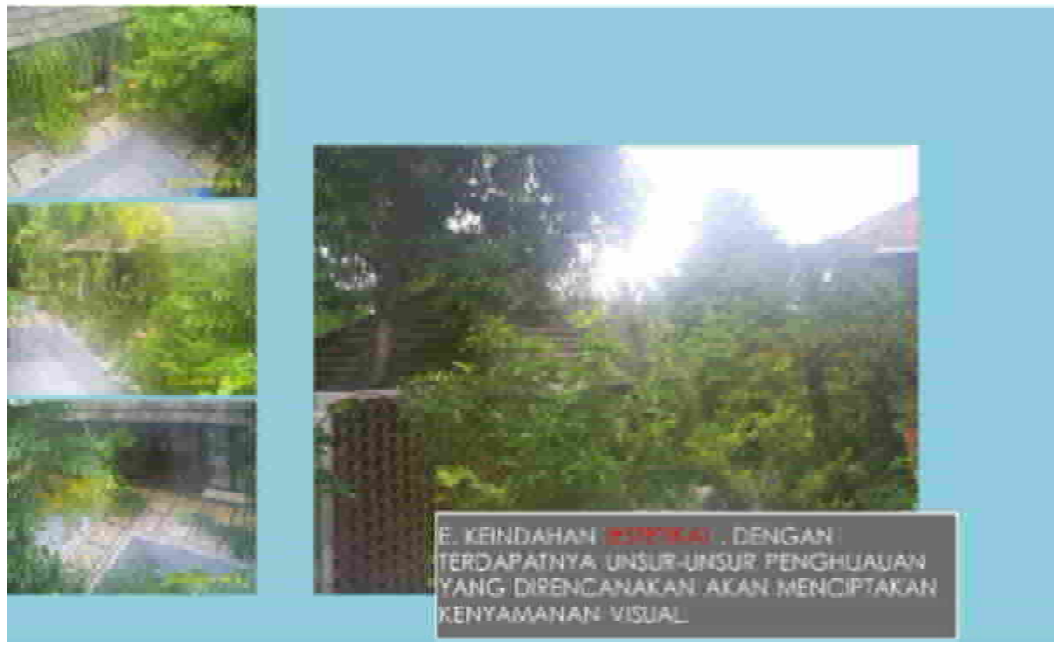

Gambar 11. Efek estetika menguat tatkala unsur penghijauan menjadi warna yang berbaur dengan tata ruang dan pola massa bangunan. Kenyamanan visualpun terasa.

Dengan kombinasi tata tanam yang terencana dan terjaga. 


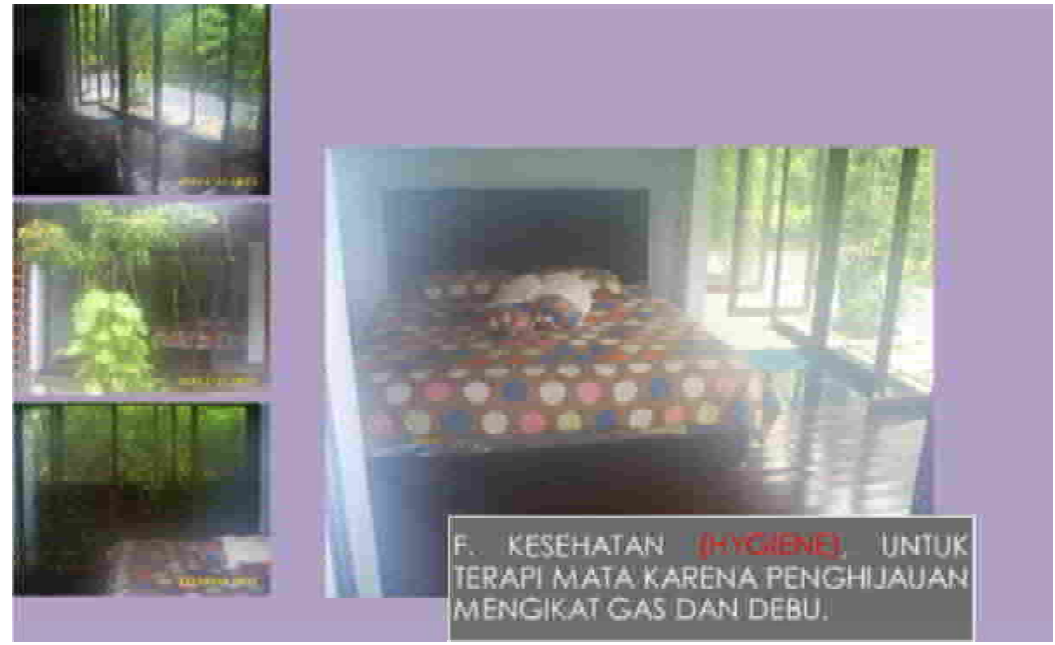

Gambar 12. Dampak positif kesehatan dapat menimbulkan energi positif vitalitas dan kulitas kehidupan.

Selain sebagai penghasil udara (O2) tanaman dapat menetralisir karbondioksida (CO2), memiliki potensi untuk mengikat partikel debu, asap, aerosol dan mengolahnya menjadi humus.

Penghijauan merupakan salah satu media efektif terapi mata,. Melihat tanaman bunga sedang berkembang, tanaman buah sedang berbuah, dan memperhatikan tingkah satwa-satwa sekitar di lingkung objek penelitian me-refresh memori- baik pengalaman kita. Menyegarkan pandangan, menumbuhkan kepekaan memori dan pengetahuan, serta mengkayakan imajinasi pemandangnya.

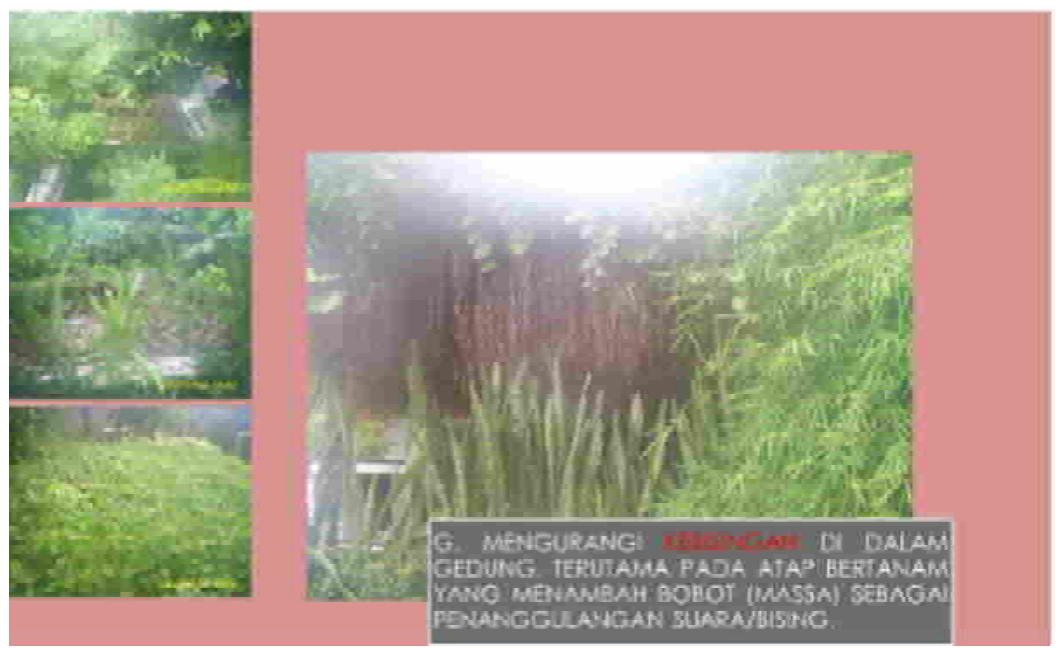

Gambar 13. Konsep green roofdiaplikasikan pada beberapa ruang yang ada pada rumah tinggal pada objek penelitian. 
Aplikasi green roof pada atap dag Rg.Toilet dan Rg.Dapur rumah tinggal, dapat membantu dalam penyerapan air hujan sebesar $50-60 \%$ ke dalam tanah mediumnya. Setelah air hujan diserap, air tersebut terevaporasi oleh tanaman ke atmosfer bumi. Sebagian air akan tetap menjadi cadangan air bagi tanaman di dalam tanah, dan sisanya dialirkan melalui saluran air (Heinz Frick, 2006).

Selain itu berperan dalam menyediakan isolasi panas karena tanaman dan media tumbuh tersebut akan menghalangi cahaya matahari langsung ke permukaan atap bangunan. Dengan demikian suhu udara ruangan di rumah memiliki suhu udara yang lebih rendah yaitu sekitar 3-4 derajat celcius dibandingkan dengan suhu udara di luar ruangan akibat proses evaporasi tanaman yang mempengaruhi suhu termal bangunan.

Dedauan yang jatuh dan dikumpulkan menjadi bahan baku kompos organik dengan cara didaur ulangkan ke permukaan tanaman, yang ada dengan sistem daur ulang 'pembusukan alami'.

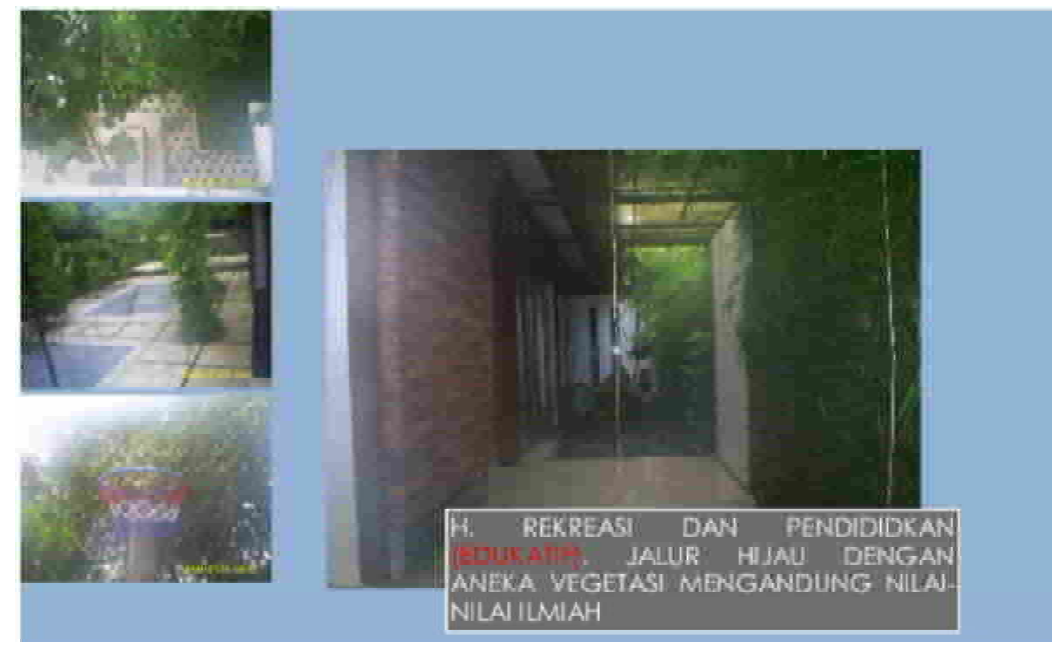

Gambar 14. Fungsi edukatif akan tata lansekap flora dengan tema aneka tanaman bunga dan buah.

Terdapatnya beberapa jenis tanaman bunga dan buah yang berneka ragam. aplikasi tata lansekap pada rumah ini, mulai dari bunga anggrek, gelombang cinta, lidah mertua, jemani, dan aneka buah seperti pohon kelapa, mangga dengan beberapa sepesiesnya, pepaya, mertega, al-keysha, juwet, kelengkeng, genitu, kesemek, rambutan, pisang, apokat, delima, sawo, durian, duku, belimbing, kepel, tinn, pepaya, jambu, sirsak, srikaya, matoa dan buah naga.

Merupakan aplikasi miniatur tanaman buah langka. Tanaman buah ini bisa dijadikan media ilmu dan pengetahuan serta kontribusi positif terhadap lingkungan sekitar.

Adanya lapangan olah raga mini 'basket' dan kolam renang untuk berenang dan berlatih berenang bagi pemula. Direncanakan kolam untuk anak dan dewasa. Selain fungsi olah raga kolam ini juga sebagai penghantar uap air dan penyejut vista. 
6. Menjamin kesinambungan pada struktur sebagai hubungan antara masa pakai bahan bangunan dan struktur bangunan,

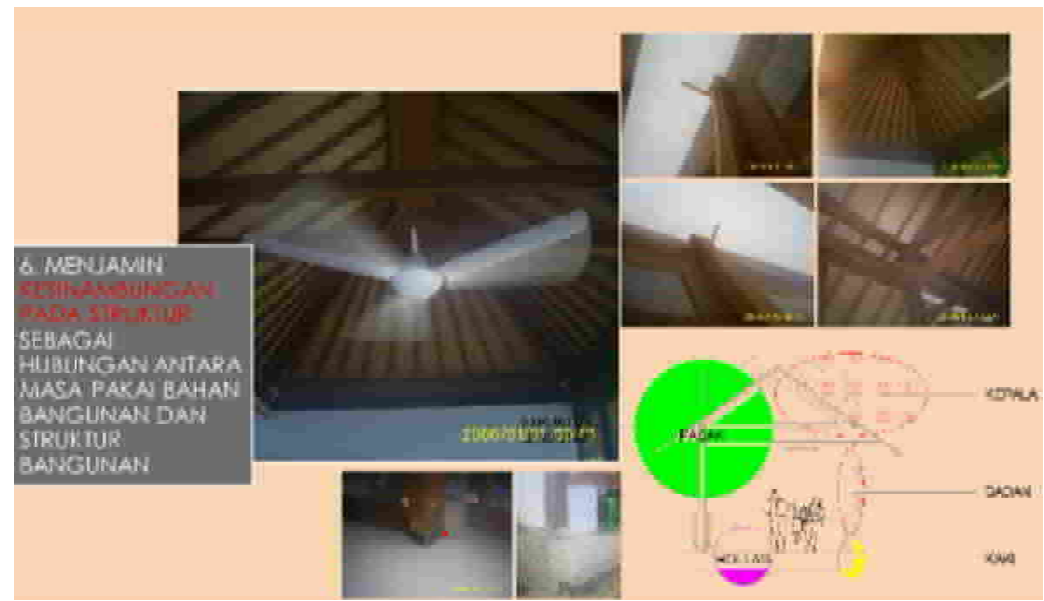

Gambar 15. Sistem struktur yang sustainble menjadi pilihan

dalam konsep perancangan rumah tinggal ini. Pemanfaatan material kayu 'kelapa lokal' dengan konstruksi knock down terinspirasi dari kekhasan arsitektur tradisional 'kampung' dengan genius loci.

Struktur bangunan rangka, dimana konsep bangunan terbuka, hanya kolom dalam aturan grid $3,5 \mathrm{~m} \times 3,5 \mathrm{~m}$ yang menerima beban. Terlihat struktur bangunan primer pada aplikasi rumah tinggal dalam objek penelitian ini. Prinsip pembentukan ruang dengan cara menyusun bagian-bagian bangunan yang menerima beban. Ciri khas ini dapat kita temui pada hubungan diantara bagian bangunan bangunan yang menerima beban (sambungan). Dengan bagian yang membagi ruang saja. dengan sistem ini sifat ruang dapat ditentukan.

Sambungan dengan purusan dan pasak sebagai pengikat antar konstruksi, menjadikan struktur atap bersifat lendutan/ tidak kaku rigid. Ringan, dan bergerak sesuai irama alam dalam adaptasinya.

7. Mempertimbangkan bentuk/proporsi ruang berdasarkan aturan harmonikal,

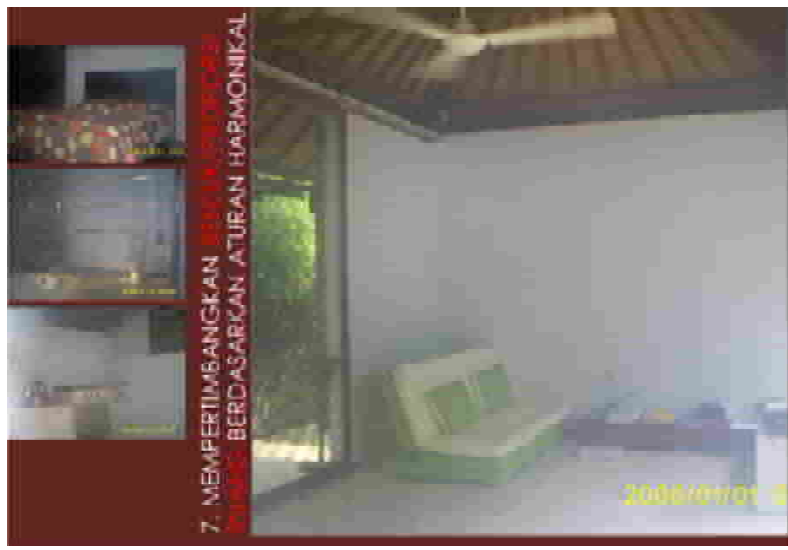

Gambar 16. Tata ruang yang nyaman dipengaruhi oleh bentuk/proporsi berdasar harmonikal. Pencahayaan, pengudaraan dan pewarnaan memberikan ambience ruang. 
Kenyamanan dan kreatifitas dipengaruhi oleh warna, seperti dapat kita pelajari dari alam sekitar dengan warna bunga, burung, kupu-kupu yang kesemuanya memiliki arti tertentu. Badan kita bereaksi sensitif terhadap rangsangan dari masing-masing warna. Warna juga memberikan suasana dan kesan pada suatu ruang.

8. Menjamin bahwa bangunan yang direncanakan tidak menimbulkan masalah lingkungan dan membutuhkan energi sesedikit mungkin,

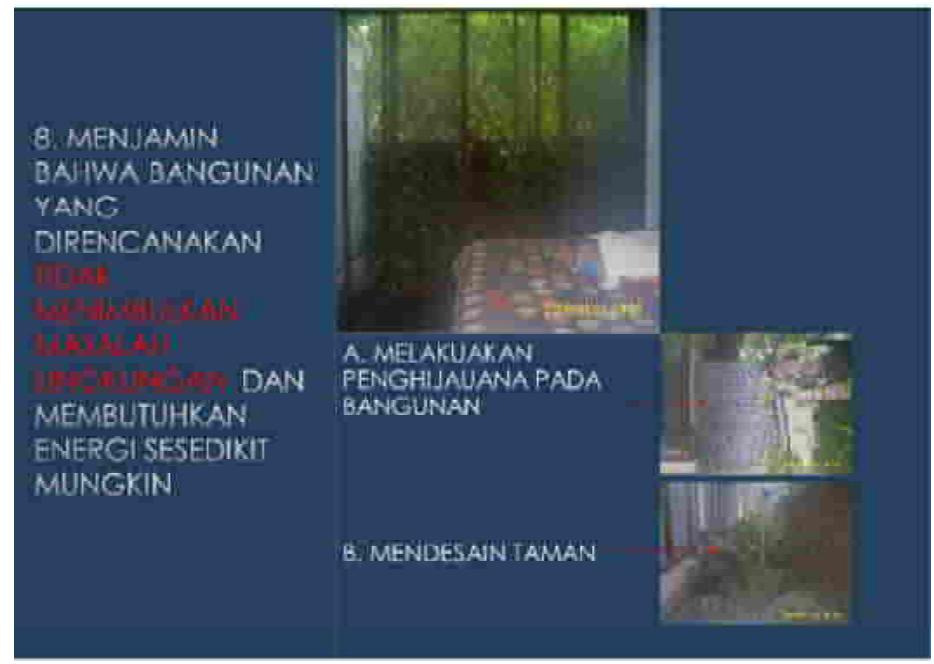

Gambar 17. Penghijauan dan penataan taman dapat meminalkan penggunaan energi disamping sebagai efek keteduhan.

Dari obyek penelitian dapat disarikan manfat penghijauan yang antara lain; sebagai pengembali daerah resapan air, menjaga kualitas air, melindungi satwa/ endhapis, mengurangi polusi, mengurangi dampak pemanasan, pengontrol iklim, mengurangi partikel debu, mencegah efek rumah kaca, suplai pupuk alami, pengontrol pemandangan, pemecah angin, pencegah erosi, dan sebagai fungsi estetika, daya saing, pendidikan, interkoneksi dan citra kawasan.

9. Menciptakan bangunan bebas hambatan sehingga gedung dapat dimanfaatkan oleh semua penghuni. Pada Objek penelitian didapatkan bahwa, rumah tinggal ini dapat digunakan disegala usia baik anak-anak mauapun orang tua, kekuranganya tidak dapat digunakan bagi orang yang difable (cacat tubuh dengan kursi roda), orang sakit, maupun orang dewasa yang sehat. Tidak diakomodasikanya jalur bagi mereka yang menggunakan kursi roda. perbedaan tingi lantai masih memadai bagi orang yang sangat tua maupun anak-anak. 
Studi Ekologis dalam Perencanaan Rumah Tinggal di Nganjuk

Juwito, Junianto HW, Erna Winarsih

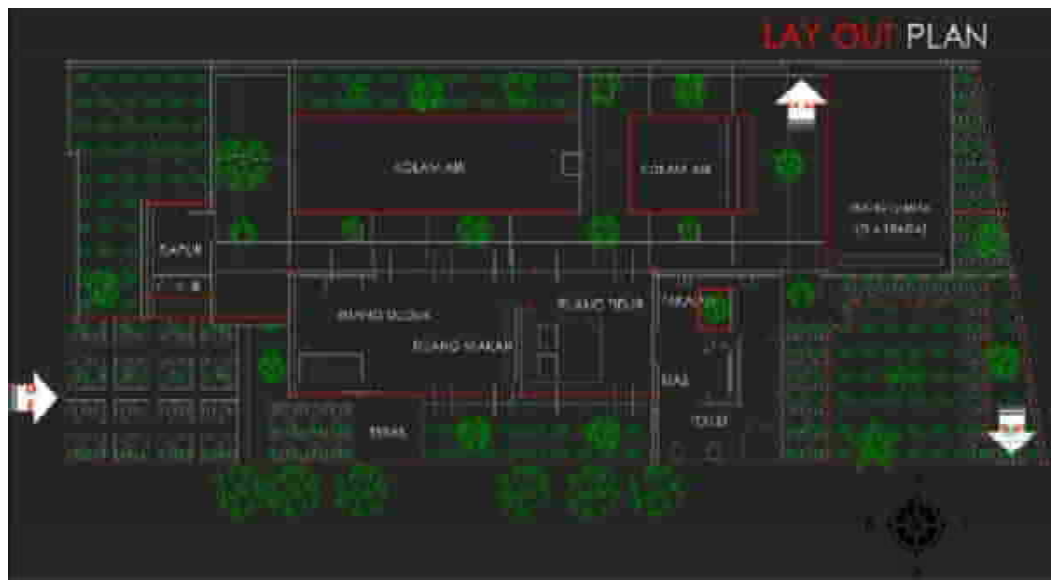

Gambar 18. Lay out plan Rumah dengan sistem terbuka, mengalir dengan arah orientasi kedalam taman introvert.

Dari ruang luar rumah berkesan tertutup, dengan pintu utama menghadap selatan atau tidak menghadap jalan. Setelah masuk teras baru terasa tata letak rumah yang terbuka menghadap kedalam tapak. Sekeliling didominasi tutupan bidang yang menghijau dengan elemen lansekapnya. Tanaman rambat menjadi pilahanya. View air dalam kolam sebagai penyejuknya.

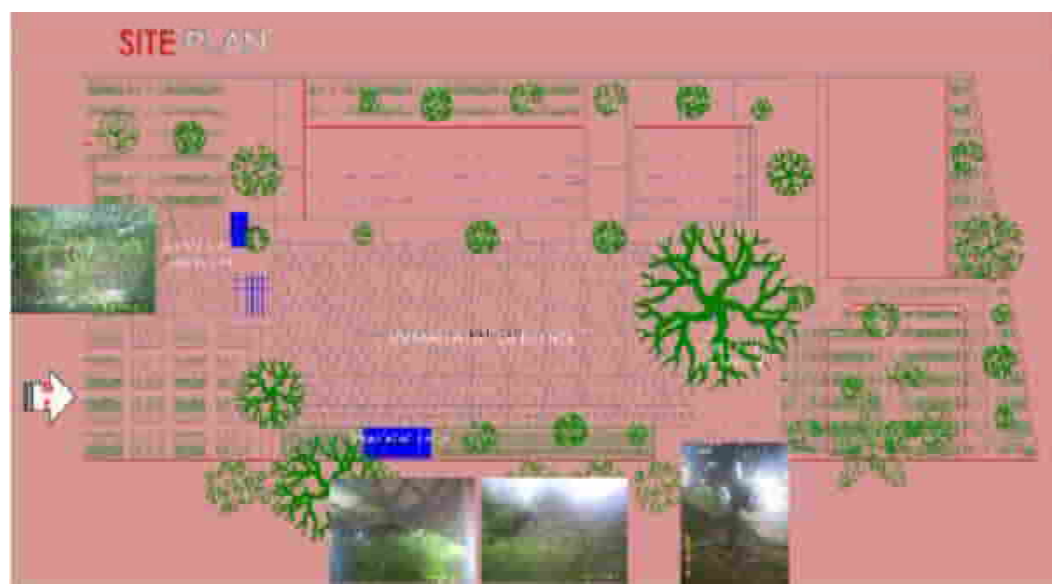

Gambar 19. Site Plan rumah induk dengan atap perisai digabungkan dengan massa toliet dan dapur dengan atap dag beton. Masing -masing massa berkontribusi terhadap bidang naunganya. 


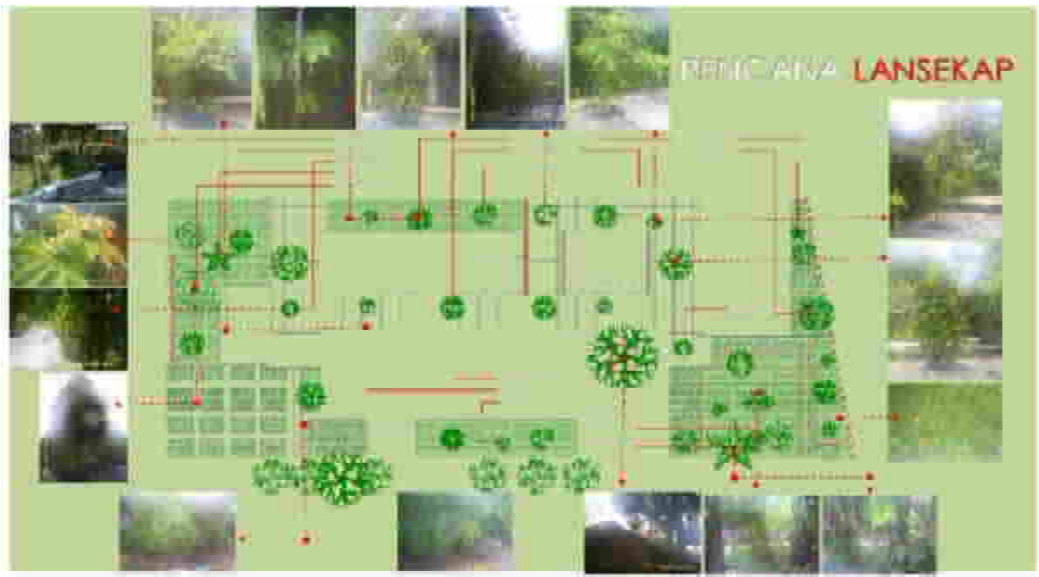

Gambar 20. Tata Lansekap dengan menghadirkan konsep tanaman bunga dan buah langka.

Tanaman bunga diletakkan pada spot terbatas lahan sebagai taman sudut, sedangkan tanaman buah langka diatur sesuai dengan karakternya. Misalkan buah yang dekat kolam air dipilih jenis buah-buahan yang daunya tidak mudah rontok, yang memiliki nilai kerapatan daun tinggi sehingga tepat untuk media pernaungan atau memiliki nilai keteduhan. tanaman buah ini direncanakan mendominasi bidang pernaungan atap. Jadi sinar sebelum menerpa atap tereduksi dedauan buah sehingga mengurangi efek terik.

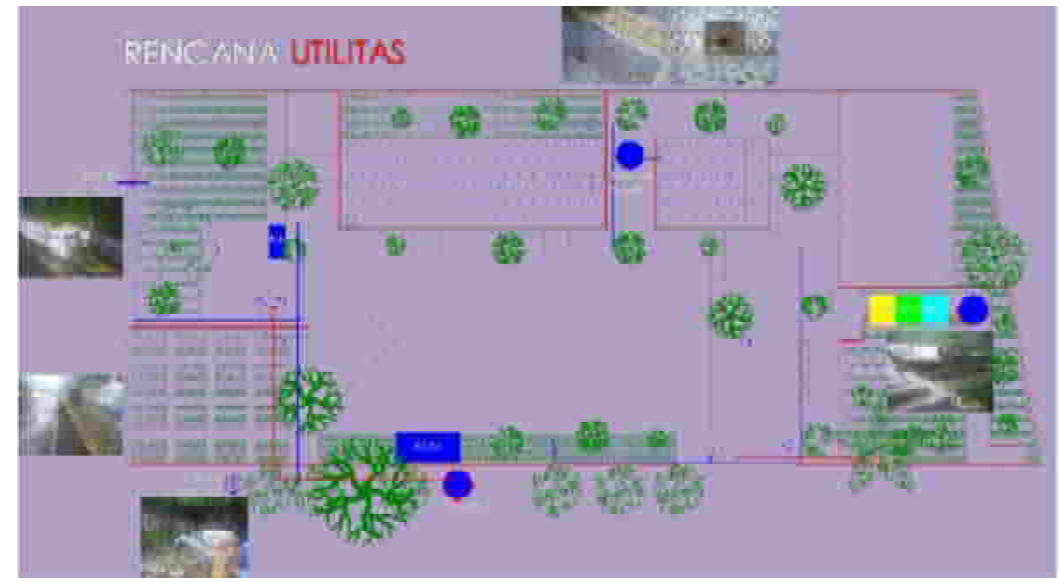

Gambar 21. Rencana Utilitas dengan Sistem daur ulang.

Sumber air bersih didapatkan dari sumber air tanah yang dipompa ke atas dan didistribusikan ke masing-masing unit. Sumber air ini letaknya ditaman depan rumah. Begitupun sumber air kolam berasal, dari 'kurasan' air kolam dimasukkan lagi ke sumur lama (terletak di tengah-tengah kolam) yang dijadikan sumur resapan air kolam (bahan baku) sumber air bersih dan dipompa naik keatas untuk sumber air kolam kembali, dengan proses filtering alami recycle. 


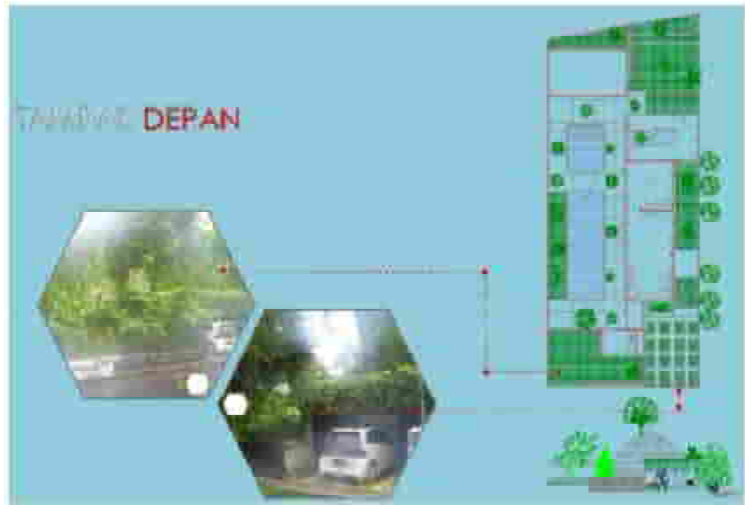

Gambar 22. Tampak Depan rumah didominasi elemen vegetasi baik berkarakter horisontal, seperti tanaman rambat, sulur-sulur maupun vertikal seperti tanaman pohon berbuah dan peneduh.

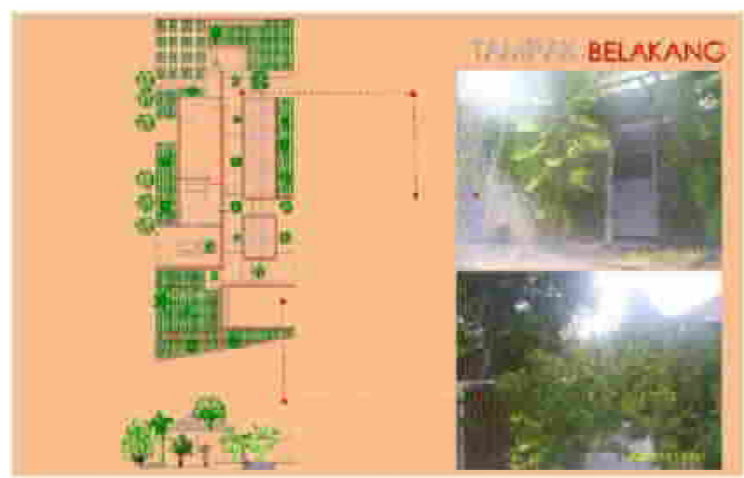

Gambar 23. Tampak Belakang rumah diisi dengan lansekap buah-buahan. Beranekaragam buah-buahan ini selain sebagai konsumsi home agriculture juga sebagai sumbangsih iklim mikro.

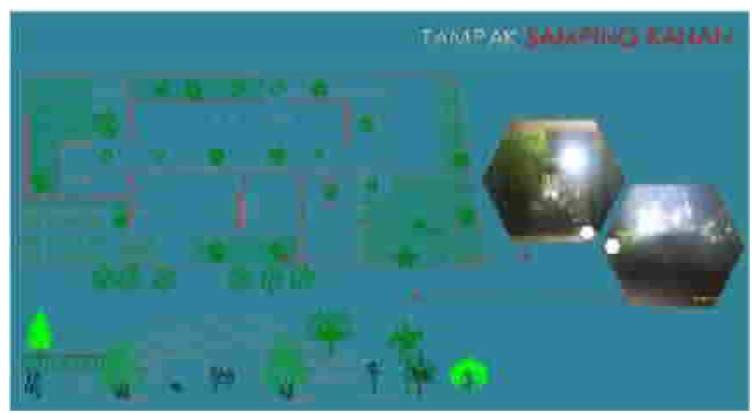

Gambar 24. Tampak Samping Kanan rumah didominasi tanaman dengan karakter penghalang pandangan, pengarah angin, penangkap partikel debu filtering juga sebagai media tumbuh kembang satwa. Seperti tanaman bambu jepang. Dengan karakter dimensinya kecil, mampu merapatkan batang dan daun yang menghasilkan media buffer serta simfoni gerakan dan suara khasnya. 
LOCAL WISDOM, Vol. 10 No. 2 Juli 2018

Local Wisdom Scientific Online Journal

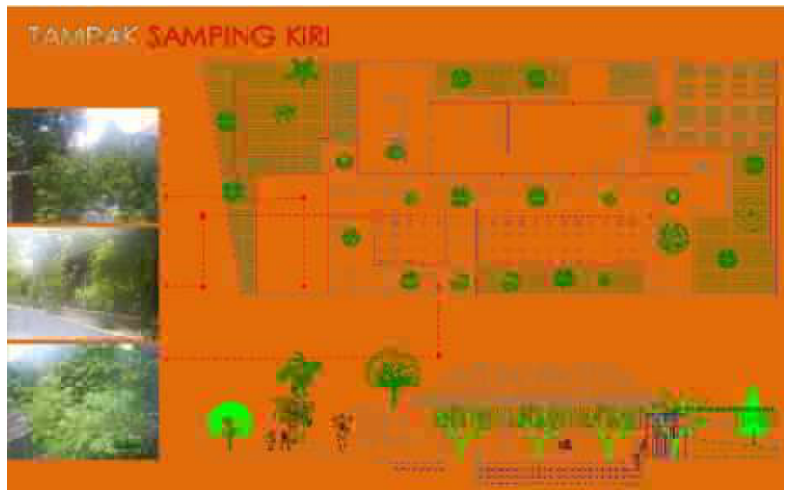

Gambar 25. Tampak Samping Kiri terlihat tanaman buah dengan spesifikasi kerapatan daun (tanam mangga eksiting). Karapatan ini mereduksi sinar matahari langsung dan tempaan air hujan, sehingga kita yang berada didalam pernaungan menjadi nyaman. Tanaman ini diarahkan tumbuh diatas penutup atap genting, baik vertikal maupun horisontal sehingga karakter negatif genteng beton yang menyerap dan menyimpan panas kedalam bangunan dapat direduksi.

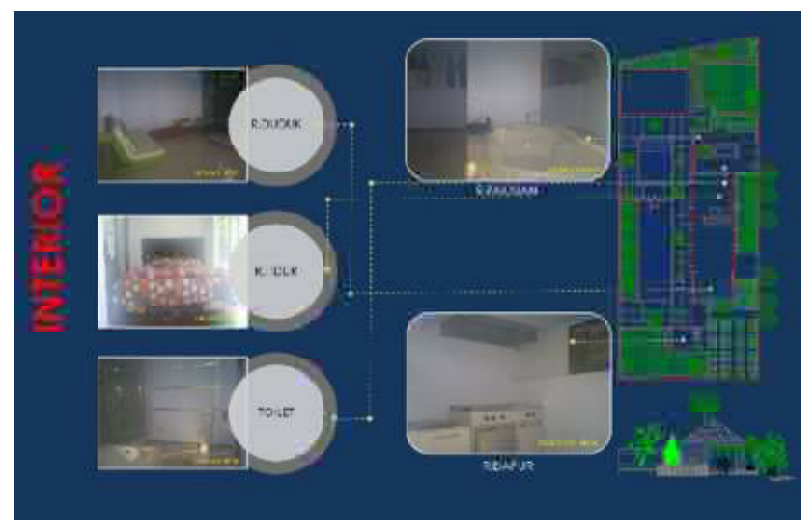

Gambar 26. Interior Ruang Dalam, baik ruang duduk, ruang tidur, toilet beserta ruang pakaian maupun ruang dapur rumah.

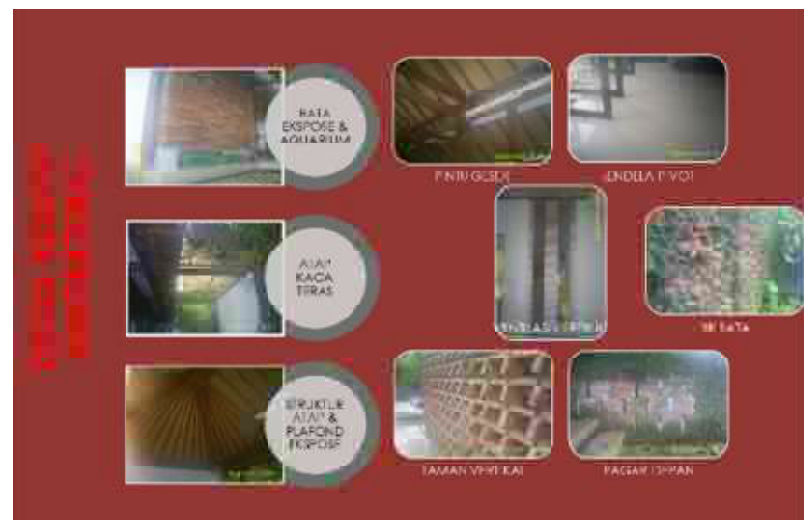

Gambar 27. Detail Kreatif Atsitektural pada dinding bata ekspose motifnya, atap teras dengan dominasi kaca transparanya, struktur atap rumah dengan material kayunya, serta detail pintu geser rumah, jendela pivot, ventilasi vertikal, $3 r$ bata, taman vertikal beserta pasangan dinding pagar. 


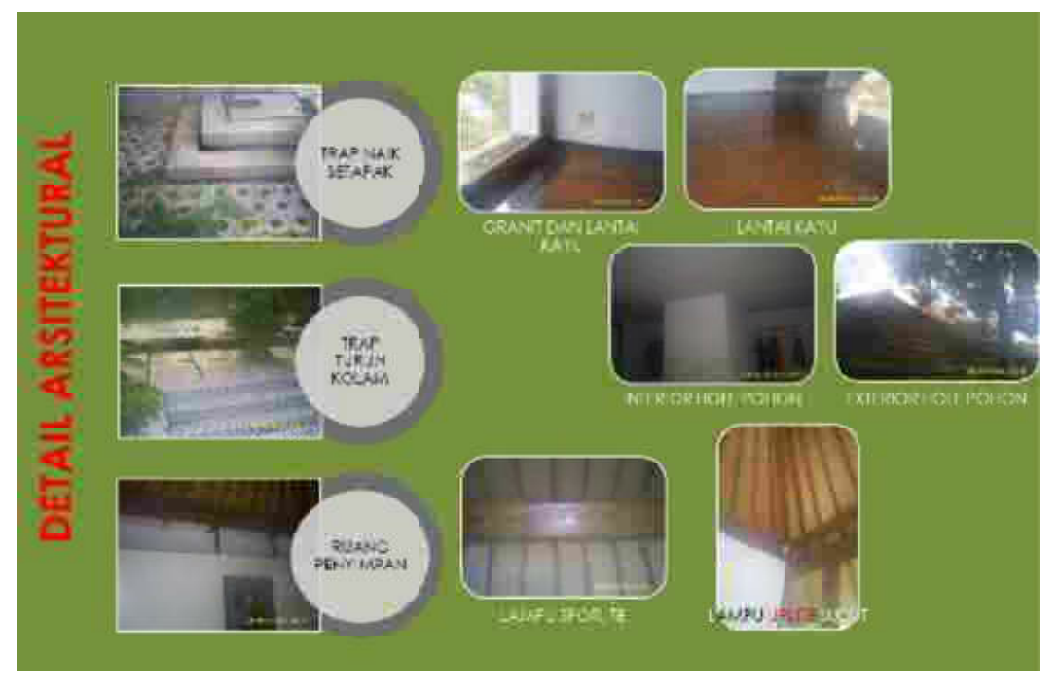

Gambar 28. Detail Arsitektural trap naik jalan setapak, trap turun kolam air, ruang penyimpan, hubungan lantai kayu, granit, interior dan eksterior bidang penutup pohon eksisting, serta lampu peneranganya.

\section{Kesimpulan}

Dari beberapa pembahasan yang berkaitan dengan penerapan arsitektur ekologis penulis membuat kesimpulan dari beberapa inti masalah yang terdapat dari tempat yang diteliti. Bahwa 'Rumah Tinggal' di Nganjuk ini, menerapkan arsitektur ekologis, dilihat dari parameter teori dalam aplikasi karya arsitektur (Heinz Frick, 2006)

Kebaruan penelitian ini menunjukkan bahwa, 'pohon besar' yang menaungi ruang dibawahnya (Rg.Toilet), (Rg.Dapur), (Teras Depan) merupakan ruangan 'favorit' hingga didapatkan Suhu paling nyaman. suhu thermal yang didapatkan berada pada rentang suhu $22,8^{\circ} \mathrm{C}-25,8^{\circ} \mathrm{C}$ dengan kelembaban $70 \%$. Cara yang paling murah memperoleh kenyamanan thermal adalah secara alamiah melalui pendekatan arsitektur, yaitu merancang bangunan dengan mempertimbangkan orientasi terhadap matahari dan arah angin, pemanfaatan elemen arsitektur dan material bangunan, serta pemanfaatan elemen-elemen lansekap. (Mohammad Irfan Meianda Putra Hamid., 2013).

Kekurangan dalam penelitian ini tidak diakomodasikanya pengguna difable. Seperti aksesibilitas dan keterjangkauan antar ketinggian lantai pengguna untuk kursi roda.

Mengingat penelitian ini membatasi identifikasi Arsitektur Ekologis 'Rumah Tinggal di Nganjuk' berdasarkan parameter Heinz Frick saja diperlukan penelitian lanjutan yang lebih komprehensif dan mendetail dengan memasukkan kajian teori-teori yang lain untuk pengkayaan khasanah arsitekturnya. 
LOCAL WISDOM, Vol. 10 No. 2 Juli 2018

Local Wisdom Scientific Online Journal

\section{Daftar Pustaka}

Adisti Safrilia., (2013) Perancangan Resort Dengan Penerapan Prinsip Ekologi Di Pulau Menjangan Kecil Karimunjawa., Artikel Ilmiah S1 UB.

Anthony C.Antoniades., (1992) Poetics of Architecture theory of design., by Van Nostrand Reinhold

Asep Yuda Permana., (2011). Penerapan Konsep Perancangan Smart Village Sebagai Local Genius Arsitektur Nusantara., Jurnal Arsitektur Komposisi, Volume 9, No. 1 April 2011.

Devina Rachmawati, Sri Nastiti NE, Gusti Ngurah

Antaryama., (2012) Konsep Desain Arsitektur Ekologis Pada Resor Di Daerah Beriklim Tropis Lembab., Paper ITS.

Diana susilowati, Irma Ramanadhia., (2013). Penerapan Arsitektur Ekologi Pada Bangunan Resort Di Kawasan Puncak.

Heinz Frick,Tri Hesti Mulyani.,Arsitektur Ekologis., Seri Eko-Arsitektur 2., Penerbit Kanisius., 2006)

Mohammad Irfan Meianda Putra Hamid., (2013). Penerapan Konsep Arsitektur Ekologis Pada Bangunan Town House Di Kawasan Cbd Polonia Medan., Tesis FT.USU

Yuliani, Sri; Samsudi; Widharyatmo., (2012). Kajian Penerapan Konsep Ekologi Arsitektur sebagai Metode Perancangan Pembangunan Berkelanjutan dalam Manajemen Pengelolaan Iklim di Daerah Tropis., FT UNS

Https://Id.Wikipedia.Org/Wiki/Arsitektur_Ekologi Diakses., Rabu, 02 Nopember 2016 Jam 01:00 